\title{
Forticept $^{\circledR}$ innovative products' effectiveness for complex udder hygiene
}

\author{
Anatoliy N. Shevchenko', Diana V. Feshchenko², Tetiana I. Bakhur ${ }^{3 *}$, \\ Oksana A. Zghozinska ${ }^{2}$, Valentyna A. Yevstafieva ${ }^{4}$, Roman N. Sachuk ${ }^{5}$, \\ Yaroslav S. Stravskiy ${ }^{6}$, Anatoliy A. Antipov ${ }^{3}$, and Vitaliy V. Melnychuk ${ }^{4}$ \\ ${ }^{1}$ Department of Veterinary-Sanitary Expertise, Microbiology, Zoohygiene and Safety and Quality of Animal \\ Products, Faculty of Veterinary Medicine, Sumy National Agrarian University, Sumy, Ukraine \\ ${ }^{2}$ Department of Parasitology, Veterinary-Sanitary Expertise and Zoohygiene, Faculty of Veterinary Medicine, \\ Zhytomyr National Agroecological University, Zhytomyr, Ukraine \\ ${ }^{3}$ Department of Parasitology and Pharmacology, Faculty of Veterinary Medicine, Bila Tserkva National Agrarian \\ University, Bila Tserkva, Ukraine \\ ${ }^{4}$ Department of Parasitology and Veterinary-Sanitary Expertise,Faculty of Veterinary Medicine, Poltava State \\ Agrarian Academy, Poltava, Ukraine \\ ${ }^{5}$ Research Epizootology Station, Institute of the Veterinary Medicine, National Academy of the Agriculture, \\ Rivne, Ukraine \\ ${ }^{6}$ Department of Medical Biology,Educational and Research Institute of Biomedical Problems, Ternopil State Medical \\ University named after Ivan Horbachevsky, Ternopol, Ukraine
}

SHEVCHENKO, A. N., D. V. FESHCHENKO, T. I. BAKHUR, O.A.ZGHOZINSKA, V. A. YEVSTAFIEVA,

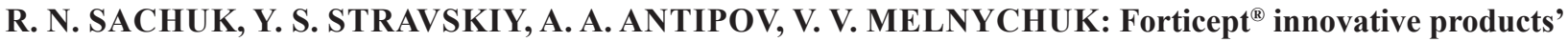
effectiveness for complex udder hygiene. Vet. arhiv 90, 565-574, 2020.

\section{ABSTRACT}

The quality of cow's milk and the spread of mastitis greatly depend on the level of udder hygiene. Our author's research was conducted to evaluate the effects of Forticept ${ }^{\circledR}$ Udder Wash and Forticept ${ }^{\circledR}$ Udder Forte, used before and after milking, on the treatment and prevention of subclinical mastitis and hyperkeratosis of cows' udders. A total of 6880 milk samples were taken from 430 cows, 3-4 years old, $470-490 \mathrm{~kg}$ weight, at $60 \pm 15$ days of lactation. The therapeutic efficacy coefficient (EC) of Forticept ${ }^{\circledR}$ polymers based on benzetonium and benzalkonium chloride, against the subclinical form of mastitis was $73.8 \%$ compared to iodine-containing agents; preventive EC - $32.4 \%$. Dipping hygiene of the udder using Forticept ${ }^{\circledR}$ on the $30^{\text {th }}$ day reduced the number of 1-3 stage teat hyperkeratosis cases from $78.8 \%$ to $41.3 \%$. Also, during this period, a significant $(\mathrm{P}<0.05)$ improvement in the chemical parameters of the milk was observed - an increase in fat (up to $3.94 \pm 0.08 \%$ ), protein $(3.35 \pm 0.07 \%)$, casein $(3.15 \pm 0.09 \%)$ and dry matter $(14.91 \pm 0.28 \%)$. After using Forticept ${ }^{\mathbb{R}}$, the total bacteria count (TBC) of the milk decreased to $3 \times 10^{5} \mathrm{CFU} / \mathrm{cm}^{3}$, and the somatic cell count (SCC) - to 130 thousand $/ \mathrm{cm}^{3}(\mathrm{P}<0.05)$. Test day milk yield (TDMY) increased by $1.15 \%$ due to efficient dipping with Forticept ${ }^{\circledR}(\mathrm{P}<0.05)$.

Key words: Forticept ${ }^{\mathbb{}}$; hyperkeratosis; subclinical mastitis; hygiene; milk

\footnotetext{
*Corresponding author:

Prof. Tetiana Bakhur, Bila Tserkva National Agrarian University, 09111 Heroiv Chornobylia st., 5, f.182, Bila Tserkva, Kyiv region, Ukraine, Bila Tserkva, Ukraine, E-mail: fly 13@i.ua
} 


\section{Introduction}

Milk quality is a multi-factor indicator. It is greatly dependent on the level of breeding work with the herd, the composition and nutritional value of rations, the hygiene of housing, and the status of cows' health (YURCHENKO and BIHUN, 2012). Any form of mammary gland inflammation adversely affects the composition and physical,chemical and biological properties of the milk (SRI BALAJI et al., 2016). A case of clinical mastitis incurred causes financial loss from 100 to 1000 euros (LITWIŃCZUK et al., 2015).

In the case of subclinical mastitis, the milk most often has no visible changes. However, after filtering such milk, tiny particles of coagulated protein can be detected in it (MURPHY et al., 2016). With the development of the inflammatory process, the somatic cell count (SCC) always increases in the mammary gland secretion (SOUZA et al., 2016; KASYANCHUK et al., 2013). The amount of chlorides and alkalinity increases in milk from affected udder quarters $(\mathrm{pH} 6.83-7.19)$. The fat content and density of this milk are reduced. There is a decrease in the solids content due to lower amounts of lactose, casein and calcium (JAGADEESH et al., 2016; NEKRASOV et al., 2018; BOGATKO et al., 2019). Reduced resistance to heat leads to spontaneous coagulation of mastitis milk during its heat treatment (PYZ-ŁUKASIK et al., 2015).

Another problem with mastitis on a farm are the inhibitors in the milk during and after the treatment of sick cows. These substances are mainly antibiotics, sulphonamides and nitrofurans (BAUMBERGER et al., 2016).

In order to ensure production of high-quality milk, it is necessary to follow the udder hygiene and regularly maintain milking machines (SACHUK et al., 2016). The functional load on the mammary gland tissue during milking creates ultimate pressure on the organ tissue (PAULRUD et al., 2005). Prone to drying, often the weathered skin of the teats is covered with cracks, around which inflammation develops, which contributes to the penetration of microorganisms into the mammary gland (NEIJENHUIS, 2004; ELESIN, 2010; GRAFF et al., 2007). Bacteria (Streptococcus spp.,
Staphilococcus spp., Trueperella pyogenes, E. coli, Klebsiella spp., etc.) are the main etiological factor of mastitis (TEGEGNE and TESFAYE, 2017). Thus, the organization of effective udder hygiene has a leading role in obtaining high quality milk (SCHROEDER, 2012).

Most preparations for mammary gland hygiene (dippingand pre-dipping) are basedon chlorhexidine, iodine and lactic acid (PRASANTHI et al., 2012; BELKIN et al., 2015). However, classic antiseptics rarely meet all contemporary requirements. These hygienic solutions should provide reliable protection against pathogenic microflora, have a beneficial effect on the skin, and be have no effect on the composition of milk (HORBATOVA and HUN'KOVA, 2010; IZQUIERDO et al., 2017).

An innovative hygienic antiseptic foaming agent for treating teats before milking, Forticept ${ }^{\mathbb{}}$ Udder Wash, contains benzalkonium chloride (BZK, $0.13 \mathrm{mg} / \mathrm{mL}$ ) as an active substance (AS). Forticept $^{\circledR}$ Udder Forte is a disinfecting filmforming preparation with a prolonged restorative effect for treating udders after milking, with AS - benzethonium chloride (BZT - $0.1 \mathrm{mg} / \mathrm{mL}$ ) and thymol $(0.063 \mathrm{mg} / \mathrm{mL})$. These preparations do not contain antibiotics, hormones and similar synthetic substances. Both preparations contain a complex of chamomile extracts (Matricaria recutita extract), yarrow (Achillea millefolium extract), and emollients (lanolin, shea butter).

The aim of the studies was to determine the effect of Forticept ${ }^{\circledR}$ Udder Wash and Forticept ${ }^{\circledR}$ Udder Forte preparations on the treatment and prevention of subclinical forms of mastitis and hyperkeratosis of cows' udders, taking into account the physicochemical and bacteriological parameters of the milk.

\section{Materials and methods}

Study population. The studies were conducted in 2018 on a private dairy farm located in the territory of Western Podolia of Ukraine (Khmelnitsky region). 430 cows were involved and 6880 milk samples were analyzed. All cows were blackpocked breed, 3-4 years old, 470-490 kg in weight, at $60 \pm 15$ days of lactation. The management and feeding conditions were identical. Daily milk yield 
Table 1. The distribution of cows into groups according to research objectives

\begin{tabular}{|c|c|c|c|c|}
\hline Group & Number of sample (n) & Clinical status & Treatment type & Research objectives \\
\hline $\begin{array}{l}\text { Experimental } \\
\text { A }\end{array}$ & $\begin{array}{c}\text { Cows }-\mathrm{n}=104 \\
\text { Milk samples - } \\
\mathrm{n}=416 \\
\text { Udder teats }-\mathrm{n}=416\end{array}$ & $\begin{array}{l}\text { SMF, } \\
\text { hyperkeratosis of } \\
\text { the teats }\end{array}$ & $\begin{array}{l}\text { Forticept } t^{\circledR} \text { Udder Wash } \\
\text { Forticept }^{\mathbb{}} \text { Udder Forte }\end{array}$ & \multirow{2}{*}{$\begin{array}{l}\text { Treatment of SMF and } \\
\text { hyperkeratosis of the } \\
\text { teats }\end{array}$} \\
\hline $\begin{array}{l}\text { Experimental } \\
\text { B }\end{array}$ & $\begin{array}{c}\text { Cows - } \mathrm{n}=104 \\
\text { Milk samples - } \\
\mathrm{n}=416 ; \\
\text { Udder teats }-\mathrm{n}=416\end{array}$ & $\begin{array}{l}\text { SMF, } \\
\text { hyperkeratosis of } \\
\text { the teats }\end{array}$ & $\begin{array}{l}\text { Iodine-containing } \\
\text { preparations }\end{array}$ & \\
\hline $\begin{array}{l}\text { Experimental } \\
\mathrm{C}\end{array}$ & $\begin{array}{c}\text { Cows }-\mathrm{n}=111 \\
\text { Milk samples }-\mathrm{n}=444\end{array}$ & Healthy & $\begin{array}{l}\text { Forticept }^{\circledR} \text { Udder Wash } \\
\text { Forticept }^{\circledR} \text { Udder Forte }\end{array}$ & \multirow{2}{*}{$\begin{array}{l}\text { Prevention of SMF and } \\
\text { hyperkeratosis of the } \\
\text { teats }\end{array}$} \\
\hline $\begin{array}{l}\text { Experimental } \\
\text { D }\end{array}$ & $\begin{array}{c}\text { Cows }-n=111 \\
\text { Milk samples }-n=444\end{array}$ & Healthy & $\begin{array}{c}\text { Iodine-containing } \\
\text { preparations }\end{array}$ & \\
\hline
\end{tabular}

SMF - subclinical mastitis form

was recorded daily using the Del Pro Farm Manager computer system (DeLaval, Tumba, Sweden). The milking procedure was carried out using linear milking machines of the type AID-1-01 (Damilk, Ukraine), twice a day. On the control days of the experiment $\left(1^{\text {st }}, 10^{\text {th }}, 20^{\text {th }}\right.$, and $\left.30^{\text {th }}\right)$, milk samples were taken individually from each cow according to DSTU (State Standard of Ukraine) ISO 707: 2002 (ISO 707:1997, IDT) and visual assessment performed of changes in the condition of the mammary gland teat skin.

Drugs and treatments. Forticept ${ }^{\circledR}$ Udder Wash (Lidan Inc., USA, Marietta) was dissolved in water (1:4) according to the instructions, before use, and the resulting solution was applied to the teat skin before milking using foaming cups, with an exposure time of $30 \mathrm{~s}$. After milking, the teats of the cows in groups A and $\mathrm{C}$ (Table 1) were dipped for 1-3 $\mathrm{s}$ in disposable glasses with Forticept ${ }^{\mathbb{B}}$ Udder Forte solution. As a result, a protective film was formed on the teats, which prevented the penetration of pathogenic microflora into the milk channel of the cow's udder before the next milking.

Standard disinfectants were used for cows in groups $\mathrm{B}$ and $\mathrm{D}$ : before milking, a solution containing $0.1 \%$ crystalline iodine was applied to the udder teats by wetting. After milking, the teats were immersed in dipping cups with a composite solution based on $0.5 \%$ useful iodine, $5 \%$ glycerol and sorbitol.
The efficiency coefficient (EC) of Forticept ${ }^{\mathbb{B}}$ products was evaluated according to the formula proposed by BRIKO (2001):

$$
\mathrm{EC}(\%)=\frac{\alpha \times 100}{\mathrm{~A}}-\frac{\beta \times 100}{\mathrm{~B}}
$$

where:

$\alpha$ - the number of healthy animals in the experimental group;

$\beta$ - the same in the control group;

A - the number of animals for experimental drug testing in the experimental group;

$\mathrm{B}$ - the number of animals for comparative drug testing in the control group.

Laboratory research. Mammary gland examinations were performed by examination, palpation, and analysis of milk samples from each quarter of the cow's udder. The subclinical mastitis form (SMF) was determined by the "California mastitis test" with Profilac Reagent N, Westfalia. The reaction was evaluated by changes in the milk's consistency in the hole of the control plate directly next to the animal. Milk from animals with questionable results of the Californian test ( + and ++ ) was rechecked by the SMF detector, «MAS-DTEC» (USA). The exact number of SC in cows'milk with SMF was measured in laboratory conditions using the device «Somacaunt-150» according to DSTU (State Standard of Ukraine) ISO 13366-2/ IDF 148-2:2014 (ISO 13366-2:2006/IDF 1482:2006, IDT). 
Milk samples for chemical and bacteriological analysis were taken individually in $100 \mathrm{~mL}$ sterile bottles, and transported on ice to the laboratory. Physical and chemical indicators of the milk (freezing point, fat, protein, casein, dry defatted milk residue (DDMR), and lactose) were determined by the analyzer Milkotester Master Classic LM3 (Bulgaria) according to DSTU (State Standard of Ukraine) ISO 9622:2013 (ISO 9622:1999, IDT) to control milk quality indicators. Samples for bacteriological analysis were prepared according to DSTU (State Standard of Ukraine) IDF 122C:2003 (IDF 122C:1996, IDT).

Total bacteria count (TBC) in the milk was determined according to DSTU (State Standard of Ukraine) ISO 4833:2006 (ISO 4833:2003, IDT); DSTU (State Standard of Ukraine) IDF 100B:2003 (IDF 100B:1991, IDT); DSTU (State Standard of Ukraine) 7357:2013.

As normative indicators for high-quality milk, we used the standard DSTU (State Standard of Ukraine) 3662-97 and Regulation (EC) No $853 / 2004$.

Statistical analysis. Mathematical analysis of the data was carried out using STATISTICA 12 for Windows (StatSoft, Inc., USA). The mean values (x) and standard deviations (SD) were calculated. The significance of differences in the average values in the studied groups was determined using the one-way analysis of variance method using the Fisher criterion. A value of $\mathrm{P}<0.05$ was considered significant.

\section{Results}

During the experiments, no deterioration in clinical condition, or development of side effects in cows under the influence of the tested drugs were observed. In the experiment (group A), udder dipping with Forticept ${ }^{\circledR}$ Udder Wash and Forticept ${ }^{\circledR}$ Udder Forte cured SMF in 59.6\% of cases already on the $20^{\text {th }}$ day of use (Fig. 1), therapeutic $\mathrm{EC}=73.8 \%$ compared to the iodine-containing agents in the control. After 30 days of Forticept ${ }^{\mathbb{R}}$ administration to healthy cows (group C), $96.4 \%$ of milk samples showed no signs of SMF, with prophylactic $\mathrm{EC}=$ $32.4 \%$.
In cows with SMF (groups A and B), teat hyperkeratosis was observed. The dipping hygiene of the udder on the $30^{\text {th }}$ day using Forticept ${ }^{\mathbb{B}}$ reduced the number of teats affected by hyperkeratosis of varying severity (stages 1-3) from the initial 78.8 to $41.3 \%$ (Fig. 2). In many cows, previously problematic teats with sphincter corpus callosum and skin cracks, became smooth, pink, elastic, without seals or damage. The number of damaged teats after using iodine-containing products for the same period decreased from 79.8 to $58.7 \%$.

The recorded improvement of the teats, regardless of the type of antiseptic hygiene used, mainly concerned cases of uncomplicated hyperkeratosis (stage 1).

Over 30 days, Forticept ${ }^{\circledR}$ preparations use tripled (from 45.2 to $15.5 \%$ ) and reduced the number of teats affected by stage 1 hyperkeratosis, completely normalizing their physiological state (stage 0). Treatment of the udder with iodine-based agents reduced the number of teats with stage 1 hyperkeratosis from 49.0 to $29.8 \%$.

The number of teats with complicated hyperkeratosis (stages 2-3) in group B cows remained almost stable $(-2.0 \%)$. The presence of rough calloused rings, cracks, inflammation of the tissues and gaping of the teat canal, in addition to the use of hygiene products during milking, requires the use of specific therapeutic drugs. However, in group $\mathrm{A}$, on the $30^{\text {th }}$ day after use of Forticept ${ }^{\mathbb{B}}$ preparations, $7.7 \%$ of the teats with stage 3 hyperkeratosis had improved to the milder stage 2 . That is, the presence of radial cracks with edema of the teat apex and the opening of the channel was replaced by the formation of coarse callosity rings with small cracks.

Improvement in the physical condition of udders after using Forticept ${ }^{\circledR}$ products led to positive changes in the composition of the milk (Table 2).

Thirty days of intensive udder hygiene in both groups and, therefore, regardless of the selected preparations'composition, led to a slight increase in milk fat, protein and lactose. However, in group A, after using Forticept ${ }^{\circledR}$ products, these indicators increased more intensively. Also, in group A, we observed an increase in casein ( $\max$ by $19.77 \%$, $\mathrm{P}<0.05$ ) and dry matter ( $\max$ by $22.72 \%, \mathrm{P}<0.05$ ) in the milk, which did not occur under the influence of iodine-containing hygienic preparations. 

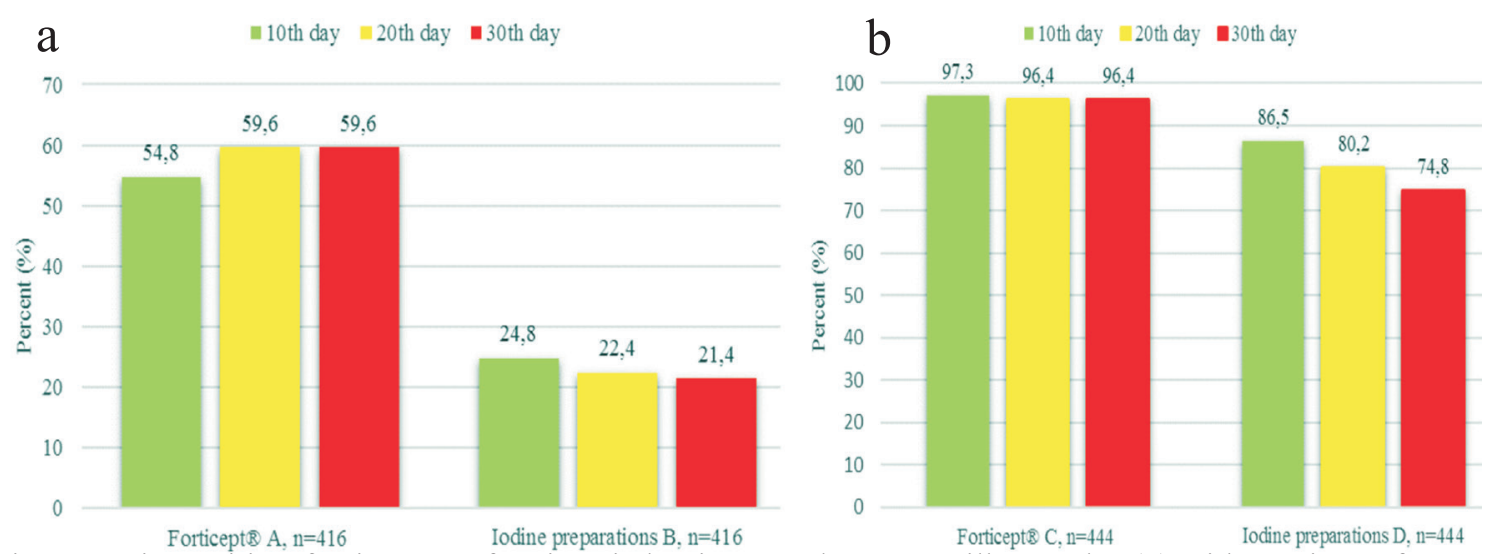

Fig. 1. Anti-mastitis effectiveness of antiseptic hygiene products, $\%$ milk samples (n) without signs of SMF: a -treatment of cows with mastitis in groups A and B; b -prevention of SMF in healthy cows in groups C and D

Table 2. Effects of antiseptic hygiene products on the chemical composition and physical properties of milk $(\mathrm{x} \pm \mathrm{SD})$

\begin{tabular}{|c|c|c|c|c|c|c|c|}
\hline \multirow[b]{2}{*}{$\begin{array}{l}\text { Experiment } \\
\text { day }\end{array}$} & \multicolumn{7}{|c|}{ Milk indicators } \\
\hline & $\begin{array}{l}\text { Fat } \\
(\%)\end{array}$ & $\begin{array}{c}\text { Protein } \\
(\%)\end{array}$ & $\begin{array}{c}\text { Casein } \\
(\%)\end{array}$ & $\begin{array}{c}\text { Lactose } \\
(\%)\end{array}$ & $\begin{array}{c}\text { Dry matter } \\
(\%)\end{array}$ & $\begin{array}{c}\text { Dry defatted } \\
\text { milk residue } \\
(\%)\end{array}$ & $\begin{array}{c}\text { Freezing } \\
\text { temperature } \\
\left({ }^{\circ} \mathrm{C}\right)\end{array}$ \\
\hline \multicolumn{8}{|c|}{ Forticept $^{\circledR} \mathrm{A}(\mathrm{n}=104)$} \\
\hline $1^{\text {st }}$ day & $3.28 \pm 0.11$ & $3.02 \pm 0.08$ & $2.63 \pm 0.07$ & $4.64 \pm 0.08$ & $12.15 \pm 0.19$ & $8.18 \pm 0.06$ & $-0.55 \pm 0.01$ \\
\hline $10^{\text {th }}$ day & $3.44 \pm 0.09$ & $3.19 \pm 0.07$ & $2.82 \pm 0.05$ & $4.74 \pm 0.09$ & $12.84 \pm 0.24$ & $8.33 \pm 0.12$ & $-0.55 \pm 0.01$ \\
\hline $20^{\text {th }}$ day & $3.61 \pm 0.09$ & $3.26 \pm 0.09$ & $2.99 \pm 0.06$ & $4.84 \pm 0.05$ & $13.70 \pm 0.30$ & $8.60 \pm 0.13$ & $-0.55 \pm 0.01$ \\
\hline $30^{\text {th }}$ day & $3.94 \pm 0.08$ & $3.35 \pm 0.07$ & $3.15 \pm 0.09$ & $4.93 \pm 0.03$ & $14.91 \pm 0.28$ & $8.92 \pm 0.08$ & $-0.56 \pm 0.01$ \\
\hline \multicolumn{8}{|c|}{ Iodine preparations B $(\mathrm{n}=104)$} \\
\hline $1^{\text {st }}$ day & $3.32 \pm 0.06$ & $2.97 \pm 0.07$ & $2.59 \pm 0.14$ & $4.69 \pm 0.07$ & $12.24 \pm 0.29$ & $8.26 \pm 0.07$ & $-0.56 \pm 0.01$ \\
\hline $10^{\text {th }}$ day & $3.48 \pm 0.07$ & $2.99 \pm 0.07$ & $2.63 \pm 0.09$ & $4.76 \pm 0.08$ & $12.38 \pm 0.23$ & $8.28 \pm 0.09$ & $-0.56 \pm 0.01$ \\
\hline $20^{\text {th }}$ day & $3.65 \pm 0.09$ & $3.12 \pm 0.08$ & $2.65 \pm 0.10$ & $4.77 \pm 0.06$ & $12.44 \pm 0.21$ & $8.33 \pm 0.09$ & $-0.57 \pm 0.01$ \\
\hline $30^{\text {th }}$ day & $3.83 \pm 0.13$ & $3.18 \pm 0.09$ & $2.61 \pm 0.08$ & $4.84 \pm 0.06$ & $12.41 \pm 0.23$ & $8.42 \pm 0.07$ & $-0.57 \pm 0.01$ \\
\hline
\end{tabular}

Table 3. Biological milk safety indicators after antiseptic hygiene products using $(\mathrm{x} \pm \mathrm{SD})$

\begin{tabular}{|c|c|c|c|}
\hline Experimentday & $\mathrm{SCC}\left(\mathrm{cell} / \mathrm{cm}^{3}\right)$ & $\mathrm{TBC}\left(\mathrm{CFU} / \mathrm{cm}^{3}\right)$ & Inhibitors \\
\hline \multicolumn{4}{|c|}{ Forticept ${ }^{\mathbb{B}} \mathrm{A}(\mathrm{n}=104)$} \\
\hline $1^{\text {st }}$ day & $507.36 \pm 5.28$ & $5 \times 10^{5}$ & absent \\
\hline $10^{\text {th }}$ day & $352.17 \pm 4.15$ & $4 \times 10^{5}$ & absent \\
\hline $20^{\text {th }}$ day & $220.44 \pm 3.67$ & $3 \times 10^{5}$ & absent \\
\hline $30^{\text {th }}$ day & $129.76 \pm 2.18$ & $3 \times 10^{5}$ & absent \\
\hline \multicolumn{4}{|c|}{ Iodine preparations $B(n=104)$} \\
\hline $1^{\text {st }}$ day & $537.36 \pm 4.14$ & $5 \times 10^{5}$ & absent \\
\hline $10^{\text {th }}$ day & $461.55 \pm 7.23$ & $4 \times 10^{5}$ & absent \\
\hline $20^{\text {th }}$ day & $346.87 \pm 5.19$ & $4 \times 10^{5}$ & absent \\
\hline $30^{\text {th }}$ day & $305.1 \pm 3.04$ & $4 \times 10^{5}$ & absent \\
\hline
\end{tabular}

SCC -somatic cell count; TBC - total bacteria count 

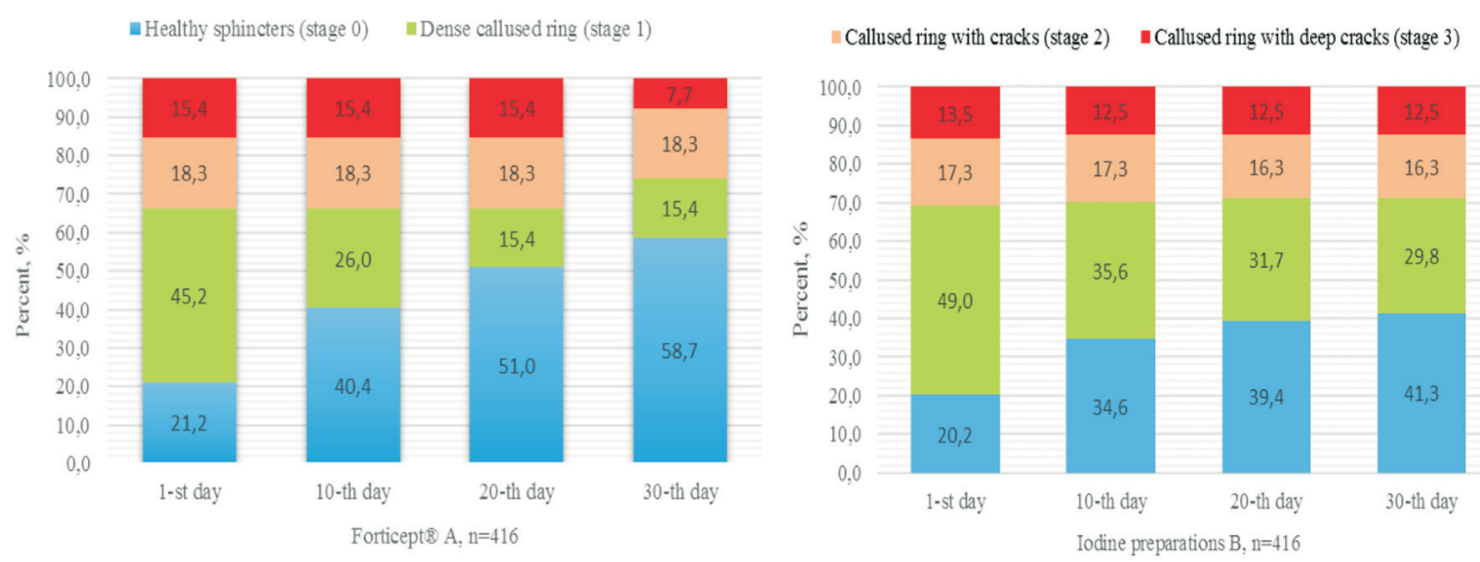

Fig. 2. Effects of antiseptic hygiene products for the condition of the teats (n) with different stages of hyperkeratosis

The applied dipping procedures during the month of the experiment in both groups significantly $(\mathrm{P}<0.05)$ improved hygienic quality of milk (Table 3). But only in experimental group A, after the use of Forticept ${ }^{\circledR}$ Udder Wash and Forticept ${ }^{\circledR}$ Udder Forte preparations, did the bacteriological indicators of milk comply with the highest national standards according to DSTU 3662-97 (State Standard of Ukraine).

The safety of testing Forticept ${ }^{\circledR}$ products was confirmed by the absence of inhibitors in milk samples in the experimental group.
In group $\mathrm{A}$, due to effective dipping with Forticept $^{\circledR}$, an increase in test day milk yield (TDMY) was observed from $29.17 \pm 0.02 \mathrm{~kg}$ on the $1^{\text {st }}$ day, to $29.51 \pm 0.02 \mathrm{~kg}$ on the $30^{\text {th }}$ day, i.e. by $1.15 \%(\mathrm{P}<0.05)$. The dynamics of TDMY in group A during the experiment period showed an upward trend (Fig. 3).

In group B, a downward trend in TDMY was observed over the same period. The decrease in the indicator at the control points ( $1^{\text {st }}$ and $30^{\text {th }}$ days) was $0.6 \%(\mathrm{P}<0.05)$ : from $29.08 \pm 0.02 \mathrm{~kg}$ to $28.9 \pm 0.02$ $\mathrm{kg}$.

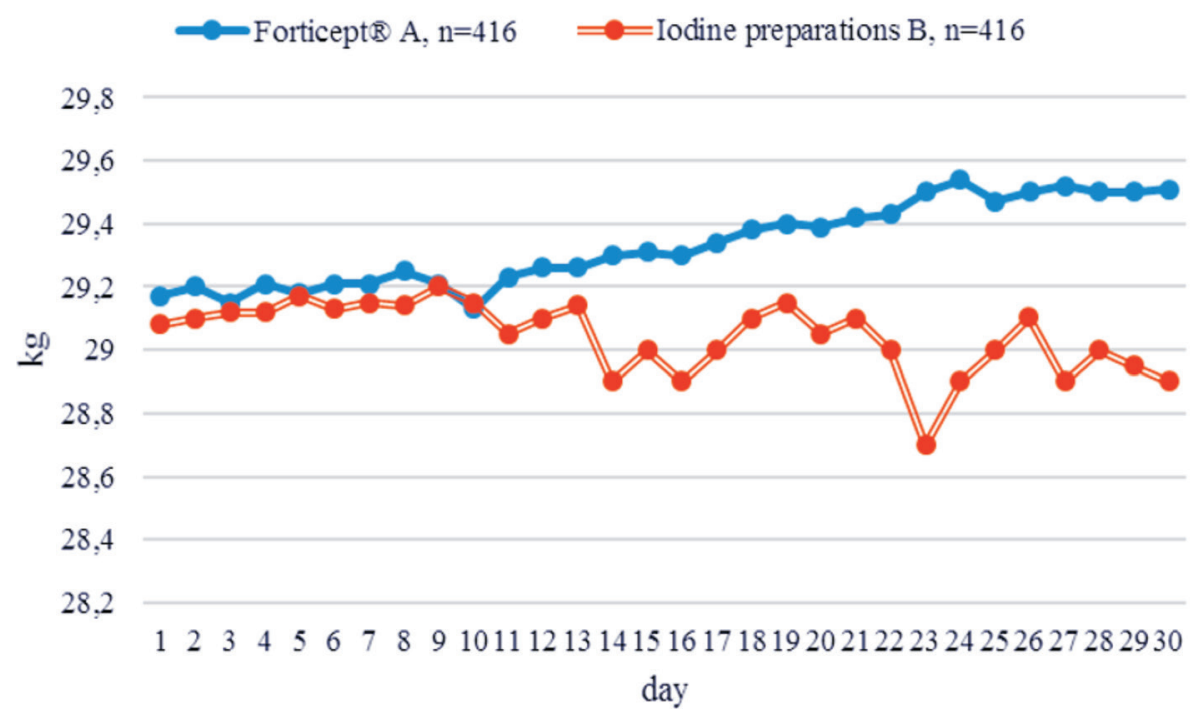

Fig. 3. Changes in test day milk yield under the influence of antiseptic hygiene products 


\section{Discussion}

Dairy farming in Ukraine, as in other countries (ABATE and WOLDE, 2015; AZEVEDO et al., 2016; ABEBE et al., 2016; KOUŘIMSKÁ et al., 2014), encounters the main problem of intensive exploitation of dairy cows: the vulnerability of highly productive animals to the influence of external negative factors. This primarily manifests itself in the form of mammary gland inflammation, mainly in SMF.

The physical, chemical and biological indicators of milk significantly worsen even in the early stages of mastitis. In the absence of clinical symptoms of the disease, pathological and inflammatory processes are already developing in the body. Many researchers have studied the quality of milk in SMF and the prospects for its processing (SILANIKOVE et al., 2014; HOQUE et al., 2015; BOGATKO et al., 2019). In fact, our results confirmed that low fat $(\sim 3.3 \%)$, protein $(\sim 3.0 \%)$, casein $(\sim 2.6 \%)$ and dry matter content $(\sim 12.2 \%)$ are observed in the milk of cows with SMF. These data explain the figures of official national statistics, according to which in Ukraine $50 \%$ of milk satisfies the criteria for extra and high class (POPKO, 2020). It should be noted that the highest class of dairy raw materials in Ukraine, according to EU standards, is assessed as only "acceptable". Thus, studies aimed at increasing the productivity of dairy enterprises in Ukraine are extremely relevant for the national economy.

The usual hygiene procedures (massage, washing the udder) do not provide reliable protection for cows from SMF. According to the latest data, the main reason of this is the open teat canal after milking, the gateway to pathogenic microflora, which is often resistant to most classical antiseptics (NETO et al., 2015; NAQVI et al., 2018). In this regard, the development of new generation germicides is a trend in veterinary pharmacology worldwide (SEMACAN et al., 2012; KNIGHTJONES et al., 2016).

In this experiment, dipping with Forticept ${ }^{\circledR}$ preparations showed high therapeutic and prophylactic anti-mastitis efficacy (EC 73.8 and $32.4 \%$, respectively). This result was achieved by intensive sanitation of the udder before milking with Forticept ${ }^{\circledR}$ Udder Wash solution, and regular use of film-forming Forticept ${ }^{\mathbb{B}}$ Udder Forte after milking, which prevented microbial colonization of the teat canal and further contamination of the milk.

Hyperkeratosis of the teats is often a favourable factor in the development of inflammation of the udder. Significant lesions in the udder epidermis (for example, deep cracks) create the conditions for the penetration of intramammary infection pathogens into the mammary gland (NEIJENHUIS, 2004; ELESIN, 2010; GRAFF et al., 2007). Thus, in addition to antibacterial components, an ideal product for hygienic treatments of the udder before milking should contain udder skin care substances. To this end, Forticept ${ }^{\circledR}$ formulas successfully combine AS and additional components. The patented composition enhances the synergy of a cleansing and antibacterial effect, and contributes to the improvement of epidermis and the neutralization of bacteria on the teats. Our own experimental data indicate that Forticept ${ }^{\circledR}$ 30-day hygiene procedures helps to treat cows with uncomplicated stage 1 hyperkeratosis, and to facilitate the course of stage 3 advanced hyperkeratosis.

Researchers often overlook the fact that the degree of teat hyperkeratosis development correlates with an increase in SCC and total bacterial contamination of raw milk (RODRIGUES et al., 2009). At the same time, the close correlation between the SCC in milk and the TDMY has been proven (PINEDO et al., 2009).

After applying Forticept $^{\circledR}$ products and improving the condition of the skin and udder parenchyma (Fig. 2), a significant (up to 4 times, $\mathrm{P}<0.05$ ) decrease in $\mathrm{SCC}$ was observed in the cows' milk (Table 3). This was additional evidence of the beneficial effect on the mammary gland physiology. There was also a significant $(\mathrm{P}<0.05)$ increase in the milk components - fat $(3.94 \pm 0.08 \%)$, protein $(3.35 \pm 0.07)$, casein $(3.15 \pm 0.09 \%)$, and dry matter $(14.91 \pm 0.28 \%)$, which increased the technological value of the milk for further processing.

Therefore, Forticept ${ }^{\circledR}$ Udder Wash as a means for hygienic treatment of cows' udders before milking, and Forticept ${ }^{\circledR}$ Udder Forte after it, may be considered effective and safe products 
for the prevention and control of SMF and teats' hyperkeratosis in a specialized livestock complex. In addition, the regular use of these products leads to an improvement in the physical and chemical parameters of cows' milk. Also, the use of Forticept ${ }^{\circledR}$ products results in a stable milk yield, with the tendency of growth. We recommend using these products for rotation with classic hygienic disinfectants (including iodine-containing) in order to reduce the incidence of SMF and the udder skin lesions in cows for machine milking.

\section{Conclusions}

Regular 30-days use of the products Forticept ${ }^{\circledR}$ Udder Wash before milking and Forticept ${ }^{\circledR}$ Udder Forte after milking, prevents (96.4\% of cases) subclinical mastitis and heals already affected udder quarters $(59.6 \%)$. The patented composition of the active substances positively affects the condition of the mammary gland skin, and can be used to prevent and facilitate the teats' hyperkeratosis. The use of these antiseptics leads to an improvement in the chemical composition of the milk (in the experiment, an increase in the percentage of fat, protein, lactose, casein and dry matter was observed, $\mathrm{P}<0.05$ ) and a significant reduction in its bacterial contamination (according to the standards of highest grade milk according to DSTU 3662-97, State Standard of Ukraine). Thus, the use of innovative Forticept ${ }^{\circledR}$ products in integrated cow udder care scheme leads to an increase in the amount of high-class milk produced.

\section{Acknowledgements}

We express our gratitude to the Director of the Institute of Animal Breeding of the National Academy of Agrarian Sciences of Ukraine Rudenko Ye. V. and the staff of the Institute for their assistance and participation in the research. Also, to the staff of the Department of Obstetrics, Gynecology and Biotechnology of Animal Reproduction of the National University of Life and Environmental Sciences of Ukraine, for their active and comprehensive support in the research.

\section{References}

ABATE, M., T. WOLDE (2015): Bacteriological quality and safety of raw cow's milk in and around Jigjiga City of Somali Region, Eastern Ethiopia. Int. J. Res. Stud. Biosci. 3, 48-55.

ABEBE, R., H. HATIYA, M. ABERA, B. MEGERSA (2016): Bovine mastitis: prevalence, risk factors and isolation of $S$. aureus in dairy herds at Hawassa milk shed, South Ethiopia. BMC Vet. Res. 12, 270.

DOI: 10.1186/s12917-016-0905-3

AZEVEDO, C., D. PACHECO, L. SOARES, R. ROMÃO , M. MOITOSO, J. MALDONADO, R. GUIX, J. SIMÕES (2016): Prevalence of contagious and environmental mastitis-causing bacteria in bulk tank milk and its relationships with milking practices of dairy cattle herds in São Miguel Island (Azores). Trop. Anim. Health Pro. 48, 451-459.

DOI: $10.1007 / \mathrm{s} 11250-015-0973-6$

BAUMBERGER, C., J. F. GUARÍN, P. L. RUEGG (2016): Effect of 2 different pre-milking teat sanitation routines on reduction of bacterial counts on teat skin of cows on commercial dairy farms. J. Dairy Sci. 99, 2915-2929.

DOI: $10.3168 /$ jds.2015-10003

BELKIN, B. L., T. V. POPKOVA, S. V. ANDREEV, V. Y. KOMAROV (2015): Efficiency of new preparations for treatment of cows' mastitis during lactation and dry period. Vestnik OrelGAU. 1, 61-66.

BOGATKO, N. M., N. V. BUKALOVA, V. P. LYASOTA, L. P. ARTEMENKO, L. M. BOGATKO, T. I. BAKHUR, T. M. PRILIPKO, I. V. ZABARNA, L. B. SAVCHUK, S. A. TKACHUK (2019): Some indices' determination of raw and pasteurized cow milk by Ukrainian manufacturers using unique express methods. J. Microbiol. Biotechnol. Food Sci. 9, 9-14.

DOI: $10.15414 /$ jmbfs.2019.9.1.9-14.

BRIKO, N. I. (2001): Criteria for evaluating the effectiveness of vaccination. Therapist. 3, 15-23 (in Russian).

ELESIN, A. B. (2010): Influence of the features of the structure of the wall of the milk tank on the damage to the tissues of the tip of the nipple in the lactation cows. Agrarian messenger of the Urals. 77, 32-33 (in Russian).

GRAFF, K., S. H. GAJDEL', G. SVAL'VE, U. BERGFEL'D (2007): Close connection of form and functionality: Morphology of nipples and udder of high-cow cows. New agriculture. 1, 84-86 (in Russian).

HOQUE, M. N., Z. C. DAS, A. K. TALUKDER, M. S. ALAM, A. N. RAHMAN (2015): Different screening tests and milk somatic cell count for the prevalence of subclinical bovine mastitis in Bangladesh. Trop. Anim. Health Pro. 47, 79-86. DOI:10.1007/s11250-014-0688-0

HORBATOVA, K. K. P. Y. HUN"KOVA (2010): Biochemistry of milk and dairy products. St. Petersburg: GIORD, 336 p. (in Russian).

IZQUIERDO, A. C., J. E. G. LIERA, R. E. CERVANTES, E. A. V. MANCERA, R. H. CRISPÍN, L. J. MOSQUEDA, A. G. VÁZQUEZ, J. O. PÉREZ, P. S. APARICIO, B. E. R. DENIS (2017): Production of milk and bovine mastitis. J. Adv. Dairy Res. 5, 174-177.

DOI: $10.4172 / 2329-888 X .1000174$ 
JAGADEESH, D. S., R. K. PUTTAMALLAPPA, H. G. KEREGALLOKOPPALU, M. LAKSHMINARASIMHIAH (2016): Prevalence of sub-clinical mastitis in cattle and effect on milk quality. Adv. Anim. Vet. Sci. 4, 237-240.

DOI: $10.14737 /$ journal.aavs/2016/4.5.237.240

KASYANCHUK, V. V., O. I. SKLYAR, O. M. BERHILEVYCH (2013): Indicator of the number of somatic cells in cow's milk's milk is an important source of information about its quality and conditions of receipt. Vet. Med. Ukr. 204, 2428 (in Ukrainian).

KNIGHT-JONES, T. J. D., M. B. HANG'OMBE, M. M. SONGE, Y. SINKALA, D. GRACE (2016): Microbial contamination and hygiene of fresh cow's milk produced by smallholders in Western Zambia. Int. J. Environ. Res. Public Health 13, 737.

DOI: 10.3390/ijerph13070737

KOUŘIMSKÁ, L., V. LEGAROVÁ, Z. PANOVSKÁ, J. PÁNEK (2014): Quality of cows' milk from organic and conventional farming. Czech. J. Food Sci. 32, 398-405.

LITWIŃCZUK, Z., J. KRÓL, A. BRODZIAK (2015): Factors determining the susceptibility of cows to mastitis and losses incurred by producers due to the disease - a review. Ann. Anim. Sci. 15, 819-831.

DOI: 10.1515/aoas-2015-0035

MURPHY, S. C., N. H. MARTIN, D. M. BARBANO, M. WIEDMANN (2016): Influence of raw milk quality on processed dairy products: How do raw milk quality test results relate to product quality and yield? J. Dairy Sci. 99, 10128-10149.

DOI: $10.3168 /$ jds.2016-11172

NAQVI, S. A., J. DE BUCK, S. DUFOUR, H. W. BARKEMA (2018): Udder health in Canadian dairy heifers during early lactation. J. Dairy Sci. 101, 3233-3247.

NEIJENHUIS, F. (2004): Teat condition in Dairy cows. Thesis (PhD). Utrecht University, Utrecht, 202.

DOI: $10.3168 /$ jds.2017-13579

NEKRASOV, R., E. KHARITONOV, Z. MAKAR, V. DUBOREZOV, A. GOLOVIN (2018): WPSI-8 Biosynthesis of milk components and vitality of cows with high and low-fat milk. J. Anim. Sci. 96, 514.

DOI: $10.1093 /$ jas/sky404.1124

NETO, S. G., R. L. OLIVEIRA, F. H. SÁ DE LIMA, A. N. DE MEDEIROS, L. R. BEZERRA, J. VIÉGAS, N. G. DO NASCIMENTO, M. D. DE FREITAS NETO (2015): Milk production, intake, digestion, blood parameters, and ingestive behavior of cows supplemented with by-products from the biodiesel industry. Trop. Anim. Health Pro. 47, 191-200.

DOI 10.1007/s11250-014-0706-2

PAULRUD, C. O., S. CLAUSEN, P. E. ANDERSEN, M. D. RASSMUSSEN (2005): Infrared thermography and ultrasonography to indirectly monitor the influence of liner type and overmilking on teat tissue recovery. Acta Vet. Scand. 46, 137-147.

DOI: $10.1186 / 1751-0147-46-137$

PINEDO, P. J., P. MELENDEZ, J. A. VILLAGOMEZCORTES, C. A. RISCO (2009): Effect of high somatic cell counts on reproductive performance of Chilean dairy cattle. J. Dairy Sci. 92, 1575-1580.

DOI: $10.3168 /$ jds.2008-1783

POPKO, O. (2020). Identification of problems and forecasting trends in the development of the Ukrainian dairy market. Inn. Technol. Sci. Sol. Ind. 1, 68-79 (in Ukrainian).

DOI: 10.30837/2522-9818.2020.11.068.

PRASANTHI, K., D. S. MURTY, N. K. SAXENA (2012): Evaluation of antimicrobial activity of surface disinfectants by quantitative suspension method. Int. J. Res. Stud. Biosci. 2, 124-127.

PYZ-ŁUKASIK, R., W. PASZKIEWICZ, M. R. TATARA, P. BRODZKI, Z. BEŁKOT (2015): Microbiological quality of milk sold directly from producers to consumers. J. Dairy Sci. 98, 4294-4301.

DOI: $10.3168 /$ jds.2014-9187

RODRIGUES, A. C., L. D. CASSOLI, P. F. MACHADO, P. L. RUEGG (2009): Short communication: evaluation of an on-farm test to estimate somatic cell count. J. Dairy Sci. 92, 990-995.

DOI: $10.3168 /$ jds.2008-1216

SACHUK, R. M., S. V. ZHYHALIUK, O. V. ZBOZHYNSKA, I. M. LUK'IANYK, H. V. SUS, N. V. MAHRELO, O. A KATSARABA (2016): Efficiency of phytoplasma in the treatment and prevention of dermatitis of dentin and mastitis in cows. Vet. Biot. 28, 247-254 (in Ukrainian).

SCHROEDER, J. W. (2012): Mastitis Control Programs. Bovine Mastitis and Milking Management. North Dakota. State University Fargo, 15.

SEMACAN, A., U. S. UÇAN, S. M. TEMIMHAN, Ü. ÇIZMECI (2012): Observations on trials of Potoclean ${ }^{\circledR}$ as a teat-dipping disinfectant. Eurasian J. Vet. Sci. 28, 54-56.

SILANIKOVE, N., M. U. ERIN, F. SHAPIRO, G. LEITNER (2014): Milk metabolites as indicators of mammary gland functions and milk quality. J. Dairy Res. 81, 358-363. DOI: $10.1017 / \mathrm{S} 0022029914000260$

SOUZA, F. N., A. F. CUNHA, D. L. ROSA, M. A. V. BRITO, A. S. GUIMARÃES, L. C. MENDONÇA, G. N. SOUZA, A. P. LAGE, M. G. BLAGITZ, A. D. LIBERA, M. B. HEINEMANN, M. M. CERQUEIRA (2016): Somatic cell count and mastitis pathogen detection in composite and single or duplicate quarter milk samples. Pesq. Vet. Bras. $36,811-818$.

DOI: $10.1590 / \mathrm{s} 0100-736 \times 2016000900004$

SRI BALAJI, N., R. SARAVANAN, A. SENTHILKUMAR, G. SRINIVASAN (2016): Effect of subclinical mastitis on somatic cell count and milk profile changes in dairy cows. Int. J. Sci. Environ. Technol. 5, 4427-4431. 
State Statistics Service of Ukraine. Retrieved from: http:// ukrstat.gov.ua (in Ukrainian).

TEGEGNE, B., S. TESFAYE (2017): Bacteriological milk quality: possible hygienic factors and the role of Staphylococcus aureus in raw bovine milk in and around Gondar, Ethiopia. Tegegne and Tesfaye Int. J. Food Contam. 4,1 .

DOI: $10.1186 / \mathrm{s} 40550-016-0046-2$
YURCHENKO, A. YU., P. P. BIHUN (2012): Assessment of the quality and safety of milk in the production of dairy products. Food Saf. Proc. Technol. 62, 206-212 (in Ukrainian).

Received: 29 October 2019

Accepted: 20 January 2020

SHEVCHENKO, A. N., D. V. FESHCHENKO, T. I. BAKHUR, O.A.ZGHOZINSKA, V. A. YEVSTAFIEVA, R. N. SACHUK, Y. S. STRAVSKIY, A. A. ANTIPOV, V. V. MELNYCHUK: Učinkovitost Forticept ${ }^{\circledR}$ inovativnog proizvoda u higijeni vimena. Vet. arhiv 90, 565-574, 2020.

\section{SAŽETAK}

Kvaliteta kravljeg mlijeka i prisutnost mastitisa uvelike ovise o razini higijene vimena. Ovo je istraživanje provedeno kako bi se ustanovila učinkovitost proizvoda Forticept ${ }^{\circledR}$ Udder Wash i Forticept ${ }^{\circledR}$ Udder Forte, upotrijebljenih prije i poslije mužnje, na liječenje i prevenciju supkliničkog mastitisa i hiperkeratoze vimena u krava. Ukupno 6880 uzoraka mlijeka uzeto je od $430 \mathrm{krava}$, dobi 3 - 4 godine, tjelesne mase $470-490 \mathrm{~kg}, 60 . \pm 15$. dan laktacije. Terapeutski koeficijent učinkovitosti (EC) polimera Forticepta ${ }^{\circledR}$, temeljen na benzetonijevu i benzalkonijevu kloridu, na supklinički oblik mastitisa bio je 73,8 \% u usporedbi s tvarima koje sadržavaju jod a preventivni koeficijent učinkovitosti (EC) 32,4 $\%$. Higijena vimena uranjanjem u Forticept ${ }^{\circledR} 30$. dan smanjila je broj slučajeva hiperkeratoze bradavica 1. - 3. stadija sa $78,8 \%$ na 41,3 \%. Također, u tom je razdoblju uočen znakovit napredak $(\mathrm{P}<0,05)$ u kemijskim pokazateljima mlijeka - porast sadržaja masnoće (do 3,94 $\pm 0,08 \%$ ), proteina $(3,35 \pm 0,07 \%)$, kazeina $(3,15 \pm 0,09 \%)$ i suhe tvari $(14,91 \pm 0,28 \%)$. Nakon upotrebe Forticepta ${ }^{\circledR}$ ukupan broj bakterija (TBC) u mlijeku smanjen je na $3 \times 10^{5} \mathrm{CFU} / \mathrm{cm}^{3}$, a broj somatskih stanica (SCC) na $130000 / \mathrm{cm}^{3}(\mathrm{P}<0,05)$. Dnevni prinos mlijeka (TDMY) porastao je za 1,15\% zahvaljujući učinkovitoj primjeni Forticepta ${ }^{\circledR}(\mathrm{P}<0,05)$.

Ključne riječi: Forticept ${ }^{\circledR}$; hiperkeratoza; supklinički mastitis; higijena; mlijeko 